\title{
KORELASI KEGIATAN EKSTRAKURIKULER KELOMPOK ILMIAH REMAJA (KIR) DENGAN KEMAMPUAN LITERASI INFORMASI
}

\author{
Pungky Septiriani*, Muakibatul Hasanah \\ Universitas Negeri Malang
}

\section{A R T I K E L}

Kata Kunci:

Hubungan

Ekstrakurikuler

Kelompok ilmiah remaja

Kemampuan literasi

informasi

\begin{abstract}
A B S T R A K
Penelitian ini bertujuan mengukur kualitas kegiatan ekstrakurikuler KIR siswa, kemampuan literasi informasi siswa, dan hubungan kualitas kegiatan ekstrakurikuler KIR dengan kemampuan literasi informasi siswa. Penelitian dengan metode kuantitatif korelasional ini menyimpulkan bahwa mayoritas siswa memiliki kualitas KIR dengan klasifikasi cukup, kemampuan literasi informasi siswa memiliki kualifikasi cukup, dan terdapat hubungan positif antara kegiatan ekstrakurikuler KIR dengan kemampuan literasi informasi siswa.
\end{abstract}

(C) 2017 BIBLIOTIKA Journal. All rights reserved

\section{PENDAHULUAN}

Kelompok Ilmiah Remaja (KIR) merupakan organisasi siswa intra sekolah yang disahkan sebagai ekstrakurikuler di tingkat SMP, SMA/SMK, Madrasah bahkan pondok pesantren sebagai wadah pengembangan kreativitas dan potensi siswa melalui kegiatan penulisan karya ilmiah. Ekstrakurikuler KIR memiliki tujuan meningkatkan kompetensi pengembangan diri siswa melalui pengembangan sikap ilmiah dalam rangka memecahkan masalah terkait fenomena alam dan sosial yang ditemui berdasarkan metode yang sistematis, objektif, rasional dan prosedural.

Urgensi pengembangan kemampuan berpikir ilmiah siswa diwujudkan dalam Keputusan Direktur Jenderal Pendidikan Dasar dan Menengah Kementrian Pendidikan dan Kebudayaan Nomor 253/KEP.D/KR/2017 tentang Penetapan Satuan Pendidikan Pelaksana Kurikulum 2013 Tahun 2017 yang mengacu pada pendekatan saintifik (saintific approach) atau pendekatan berbasis keilmuan. Implementasi kurikulum 2013 tidak diwujudkan dalam program belajar di dalam jam pelajaran saja, tetapi juga diwujudkan dalam program kegiatan ekstrakurikuler KIR dan program literasi sekolah.

Urgensi pengembangan program literasi, khususnya literasi informasi sebagai jalan untuk meningkatkan kemampuan berpikir ilmiah siswa diungkapkan oleh CONUL (2004:6), bahwa literasi informasi dapat memperjelas pemahaman siswa tentang proses penelitian, menghasilkan karya ilmiah yang lebih baik, meningkatkan keterampilan penggunaan sumber informasi, menghindari plagiarisme dan meningkatkan keberhasilan belajar siswa.

Paparan tersebut menunjukkan bahwa kegiatan penelitian dan penulisan karya ilmiah berhubungan dengan kemampuan literasi informasi. Penelitian tentang literasi informasi pernah dilakukan oleh Wijayanty (2010), bahwa kemampuan literasi informasi berdasarkan standar literasi informasi tingkat sekolah AASL tahun 1998 siswa kelas VII SMP Negeri 4 Depok dalam mengerjakan makalah adalah baik, dan penelitian oleh Hidayati (2011), bahwa keterampilan proses sains dan sikap ilmiah siswa anggota KIR lebih tinggi daripada siswa bukan anggota KIR, serta menjelaskan bahwa kegiatan ekstrakurikuler KIR berpengaruh terhadap keterampilan proses sains dan sikap ilmiah siswa MAN Brebes 1.

\section{METODE}

Penelitian ini merupakan penelitian kuantitatif korelasional. Penelitian korelasi merupakan jenis penelitian yang menunjukkan hubungan antara dua variabel tanpa menunjukkan hubungan sebab-akibat. Menurut Suharsaputra (2012:42), "Penelitian korelasi pada dasarnya hanya menunjukkan tentang adanya hubungan antara dua variabel atau

\footnotetext{
${ }^{*}$ Corresponding author.

E-mail addresses: pseptiriani@yahoo.com (Pungky Septiriani), muakibatulhasanah@yahoo.co.id (Muakibatul Hasanah)
} 
lebih mengenai besarnya hubungan tersebut. Ini berarti bahwa korelasi tidak menunjukkan hubungan sebab akibat". Dengan demikian penelitian ini berfokus pada pengukuran tingkat hubungan antara kegiatan ekstrakurikuler KIR dan kemampuan literasi informasi siswa.

Sebelum mengumpulkan data, keabsahan instrumen penelitian diukur melalui uji validasi instrumen oleh ahli dan pengujian instrumen di lapangan. Validasi oleh ahli dilakukan melalui diskusi dengan dosen pembimbing. Pengujian instrumen di lapangan dilaksanakan di SMA Negeri 5 Malang. Pengambilan sampel untuk uji instrumen dilakukan dengan teknik yang sama dengan pengambilan sampel penelitian, yaitu teknik sampling jenuh atau sampel sensus dengan total responden sebanyak 50 siswa. Menurut Sugiyono (2006:61), teknik penyampelan jenuh atau penyampelan sensus adalah teknik pengambilan sampel apabila semua anggota populasi dipilih sebagai sampel penelitian. Data hasil uji instrumen kemudian dilakukan uji daya beda, uji tingkat kesukaran butir soal dan uji validitas isi butir soal. Hasil pengujian kemudian didiskusikan kembali dengan dosen pembimbing sehingga diperoleh saransaran perbaikan instrumen.

Penelitian ini menggunakan dua jenis instrumen, yaitu tes dan angket sebagai alat pengambilan data. Menurut Harsiati (2011:41), "Tes diartikan sebagai alat yang dipergunakan untuk mengukur pengetahuan atau penguasaan objek ukur terhadap seperangkat konten dan materi tertentu". Tes yang digunakan dalam penelitian ini adalah tes KIR berbentuk pilihan ganda (multiple choice) beserta pedoman penyekoran dan tes literasi informasi berbentuk pilihan ganda (multiple choice) beserta pedoman penyekoran. Tes kemampuan penulisan karya ilmiah dituangkan dalam 11 butir pertanyaan sedangkan tes kemampuan literasi informasi dituangkan dalam delapan butir pertanyaan.

Angket merupakan sejumlah pertanyaan tertulis yang digunakan untuk memperoleh informasi tentang apa yang dialami dan diketahui oleh responden (Aedi, 2010:4). Tingkat motivasi responden terhadap variabel penelitian, intensitas keikutsertaan responden, dan hal-hal yang bersifat personal diukur melalui pertanyaan tertutup maupun pertanyaan terbuka. Angket penelitian ini digunakan untuk mengukur intensitas keikutsertaan siswa dalam mengikuti kegiatan ekstrakurikuler KIR melalui enam pertanyaan semi terbuka dan satu pertanyaan tertutup. Kemudian untuk mengetahui intensitas kegiatan literasi informasi dan tingkat pemahaman siswa terhadap literasi informasi, peneliti menggunakan 16 pertanyaan semi terbuka dan 17 pertanyaan tertutup melalui angket literasi informasi.

Berdasarkan hasil pengerjaan tes dan hasil pengisian angket, diperoleh data berupa nilai tes dan nilai angket siswa. Nilai tersebut diperoleh berdasarkan pedoman penyekoran. Nilai tersebut kemudian disesuaikan dengan tabel kualifikasi kualitas KIR untuk menentukan siswa yang berkualitas baik, cukup, atau kurang dalam mengikuti kegiatan KIR. Nilai rata-rata kemampuan literasi informasi juga diklasifikasikan berdasarkan tabel kualifikasi literasi informasi untuk menentukan kualifikasi nilai literasi informasi siswa siswa; sangat tinggi, tinggi, cukup dan rendah.

Pemberian tes dan angket secara langsung kepada seluruh sampel penelitian yang ditentukan dengan teknik penyampelan Jenuh atau penyampelan Sensus dilakukan pada tanggal 8 dan 10 April 2017. Seluruh siswa anggota ekstrakurikuler KIR SMA Negeri 2 Malang yang berjumlah 16 siswa dipilih sebagai sampel penelitian. Data yang diperoleh adalah data numerik berupa nilai tes dan angket KIR, serta nilai tes dan nilai angket kemampuan literasi informasi.

Analisis data dilakukan secara matematis melalui perhitungan statistik menggunakan bantuan program SPSS 16.0 for Windows untuk mengurangi resiko kesalahan perhitungan. Uji persyaratan analisis dilakukan untuk menentukan kelayakan sampel penelitian. Uji prasyarat tersebut meliputi uji nomalitas Kolmogorov-Smirnov dan uji homogenitas LEVENE untuk menentukan jenis analisis statistik yang digunakan dalam pengujian hipotesis. Menurut Riadi (2016:105), syarat-syarat dalam uji statistik parametrik adalah data yang digunakan harus memenuhi asumsi klasik seperti asumsi normalitas, homogenitas,...dan harus berskala interval atau rasio. Apabila hasil uji prasyarat menunjukkan sebaran data normal dan homogen, maka pengujian hipotesis dapat dilakukan dengan analisis statistik parametrik, uji korelasi Product Moment Pearson. Apabila hasil uji prasyarat tidak menunjukkan sebaran data normal dan homogen, maka pengujian hipotesis dilakukan dengan analisis statistik nonparametrik.

\section{HASIL PENELITIAN}

\section{Kualitas Kegiatan Ekstrakurikuler KIR}

Hasil penelitian menunjukkan bahwa siswa anggota KIR memiliki rata-rata skor kualitas kegiatan ekstrakurikuler KIR dengan klasifikasi cukup (skor 1.38). Rata-rata terendah (skor 0) ditunjukkan oleh siswa dengan kualitas kurang. Rata-rata tertinggi (skor 3) ditunjukkan oleh siswa dengan kualitas baik. Sebanyak enam siswa (37.5\%) memiliki kualitas kurang, sembilan siswa (56.25\%) memiliki klasifikasi cukup, dan sisanya, satu orang siswa (6.25\%) memiliki kualitas kegiatan KIR yang baik. Penelitian juga menunjukkan bahwa siswa dengan kualitas kurang menunjukkan intensitas kegiatan KIR yang paling rendah (20.37\%) daripada siswa dengan kualitas cukup (56.8\%) dan siswa berkualitas baik (100\%).

Siswa anggota KIR SMA Negeri 2 Malang menunjukkan keterampilan menulis karya ilmiah dengan rata-rata skor 4. Rata-rata terendah (skor 2) ditunjukkan oleh siswa dengan kualitas kurang. Rata-rata tertinggi (skor 7) ditunjukkan oleh siswa dengan kualitas cukup. Keterampilan menulis karya ilmiah siswa berkualitas baik menunjukkan presentase paling rendah (49.26\%) daripada keterampilan menulis karya ilmiah siswa dengan kualitas kurang (54.7\%) dan siswa berkualitas cukup (60.82\%). Pada keterampilan menulis karya ilmiah siswa aspek sistematika, siswa dengan kualitas kurang menunjukkan perolehan nilai tertinggi (50\%) daripada siswa dengan kualitas cukup $(40.7 \%)$ dan siswa dengan kualitas baik (33.3\%). Pada keterampilan menulis karya ilmiah aspek pengembangan gagasan, siswa dengan kualitas baik menunjukkan nilai tertinggi (87.5\%). Pada keterampilan menulis karya ilmiah aspek pengggunaan bahasa, siswa dengan kualitas kurang menunjukkan keterampilan paling tinggi (61\%). Pada keterampilan menulis karya ilmiah aspek ejaan, siswa berkualitas baik menunjukkan nilai tertinggi (100\%). Pada keterampilan menulis karya ilmiah aspek tata tulis, siswa berkualitas baik menunjukkan perolehan nilai paling tinggi. 


\section{Kemampuan Literasi Informasi Siswa}

Seluruh anggota ekstrakurikuler KIR memilkiki kualifikasi kemampuan literasi informasi cukup dengan ratarata 58.8\%. Kemampuan literasi informasi siswa dengan kualitas cukup menunjukkan presentase paling tinggi (60.29\%). Siswa dengan kualitas kurang menunjukkan kemampuan literasi informasi lebih rendah (58.5\%) dan siswa dengan kualitas baik menunjukkan kemampuan literasi informasi paling rendah (46.78\%). Ketiga nilai tersebut berada pada rentang kualifikasi kemampuan literasi informasi cukup.

\section{Uji Prasyarat Analisis Statistik}

Hasil uji prasyarat analisis statistik parametrik menunjukkan bahwa nilai kualitas kegiatan KIR dan nilai kemampuan literasi informasi siswa memiliki nilai probabilitas atau Sig $(0.955)>0.05$ dan Sig $(0.808)>0.05$ sehingga dapat disimpulkan bahwa kedua nilai terdistribusi normal. Uji homogenitas data nilai kualitas kegiatan KIR menunjukkan nilai probabilitas atau Sig $(0,563)>0,05$ dan $F_{\text {hitung }}(0,607)<\mathrm{F}_{\text {tabel }}(3,087)$ dan data nilai kemampuan literasi informasi siswa menunjukkan nilai probabilitas atau $\operatorname{Sig}(0,583)>0,05$ dan $F_{\text {hitung }}(0,730)<\mathrm{F}_{\text {tabel }}(3,087)$. Dengan demikian, dapat disimpulkan bahwa kedua data bersifat homogen atau memiliki varian yang indentik sehingga hipotesis penelitian dapat diuji menggunakan analisis statistik parametrik uji korelasi product moment pearson.

\section{Uji Korelasi Kegiatan Ekstrakurikuler KIR dengan Kemampuan Literasi Informasi Siswa}

Hasil uji prasyarat menunjukkan bahwa pengujikan hipotesis dapat dilakukan dengan menggunakan statistik parametris uji korelasi product moment pearson dengan rumus $\mathrm{r}_{\text {hitung }}=\frac{N \Sigma X Y-(\Sigma X)(\Sigma Y)}{\sqrt{(N \Sigma X 2-(\Sigma X Y) 2]-[N \Sigma X 2-(\Sigma Y) 2]^{\prime}}}$, dengan $X$ sebagai skor instrumen yang akan dicari validitasnya, $y$ adalah skor instrumen yang dijadikan sebagai standar (kriteria), dan $r_{\text {hitung }}$ adalah koefisien korelasi antara variabel $\mathrm{x}$ dan $\mathrm{y}$. Koefisien korelasi merupakan perwujudan dari tingkat hubunga antara kedua variabel. Menurut Sami' an (2006:3), "Besar kecilnya hubungan antara dua variabel dinyatakan dalam bilangan yang disebut koefisien korelasi".

Pengambilan keputusan statistik dapat dilakukan dengan dua cara, yaitu pertama, membandingkan koefisien korelasi dengan nilai $r_{\text {tabel. }}$. Apabila nilai koefisien korelasi $>r_{\text {tabel }}$ maka terdapat korelasi yang signifikan. Sebaliknya, apabila nilai koefisien korelasi $<r_{\text {tabel }}$ maka tidak terdapat korelasi yang signifikan. Nilai koefisien korelasi tersebut disesuaikan dengan tabel interpretasi nilai korelasi untuk mendapatkan kesimpulan yang lebih spesifik.

Nilai $\mathrm{r}_{\text {hitung }}$ (Pearson Correlation) menunjukkan besar hubungan antara kedua variabel. Dua variabel dinyatakan tidak terdapat korelasi sama sekali apabila memiliki nilai determinan 0. Sebaliknya jika determinan bernilai 1 maka kedua variabel memiliki korelasi sempurna. Hal ini berarti jika nilai determinan mendekati -1 atau 1 , maka korelasi antara kedua variabel juga semakin kuat. Sebaliknya, jika nilai determinan mendekati 0 , maka hubungan kedua variabel semakin lemah (Suharsaputra, 2012:129).

Cara kedua, adalah dengan membandingkan nilai signifikansi dengan taraf signifikansi $(\alpha)$ yang bernilai 0.05 Apabila nilai Sig. $<0.05$ maka terdapat korelasi yang signifikan. Sebaliknya, apabila nilai Sig. $>0.05$ maka tidak terdapat korelasi yang signifikan (Sami' an, 2006:16).

Hasil perhitungan uji korelasi kegiatan ekstrakurikuler KIR dengan kemampuan literasi informasi siswa dengan jumlah data $(\mathrm{N})$ sebanyak 16 , menunjukkan koefisien korelasi $\left(\mathrm{r}_{\text {litung }}\right)$ sebesar $0.101<\mathrm{r}_{\text {tabel }}(2.15)$. Hal ini menunjukkan bahwa tidak terdapat korelasi signifikan antara kegiatan ekstrakurikuler KIR dan kemampuan literasi informasi siswa SMA Negeri 2 Malang.

Uji korelasi juga menunjukkan nilai signifikansi sebesar $0.709>0.05$. Dengan demikian dapat diketahui bahwa tidak terdapat korelasi yang signifikan antara kegiatan ekstrakurikuler KIR dan kemampuan literasi informasi siswa SMA Negeri 2 Malang. Nilai determinan sebesar 0.101. Angka tersebut menunjukkan bahwa tingkat hubungan antar kedua variabel sangat lemah.

Tanda nilai $\mathrm{r}_{\text {hitung }}$ menentukan hubungan antara kedua variabel. Tanda positif menunjukkan bahwa hubungan kedua variabel berbanding lurus atau memiliki korelasi positif. Sebaliknya, tanda negatif pada nilai $\mathrm{r}_{\text {hitung }}$ menunjukkan bahwa kedua variabel memiliki korelasi negatif. Hasil uji korelasi menunjukkan bahwa $r_{\text {hitung }}$ penelitian ini bernilai positif. Dengan demikian kegiatan ekstrakurikuler KIR memiliki hubungan positif dengan kemampuan literasi informasi.

\section{PEMBAHASAN}

\section{Kualitas Kegiatan Ekstrakurikuler KIR}

Pengelompokan responden berdasarkan tingkatan kualitas keikutsertaan mereka dalam program kegiatan ekstrakurikuler KIR yang dipilah menjadi tiga tingkatan, yaitu baik, cukup dan kurang dilakukan untuk mengetahui kesungguhan siswa dalam mengikuti program kegiatan KIR. Kesungguhan siswa diukur melalui perolehan rata-rata nilai intensitas dan nilai keterampilan menulis siswa. Siswa yang bersungguh-sungguh dalam mengikuti kegiatan KIR, tidak hanya menunjukkan intensitas partisipasi kegiatan KIR yang tinggi, melainkan juga menunjukkan keterampilan menulis karya ilmiah yang tinggi pula. Dengan kata lain, intensitas kegiatan ekstrakurikuler KIR hakikatnya memiliki hubungan positif dengan keterampilan menulis karya ilmiah siswa.

Hubungan tersebut dikuatkan oleh dua ahli berikut. Menurut Tarigan (2008) yang dikuatkan oleh Zainurrahman (2011:2), keterampilan menulis dan membaca hanya dapat diperoleh dan dikembangkan melalui penguasaan konsep-konsep teoretis tertentu, disertai dengan latihan-latihan. Menurut Wardani (2006:1.5), "Menulis karya ilmiah adalah suatu keterampilan seseorang yang didapat melalui berbagai latihan menulis". 
Kualitas kegiatan ekstrakurikuler KIR siswa diukur melalui rata-rata nilai tes dan angket KIR yang diseuaikan dengan Tabel Kualifikasi Kualitas Kegiataan KIR. Hasil penelitian menunjukkan bahwa siswa dengan kualitas KIR yang baik justru tidak memiliki intensitas kegiatan KIR yang tinggi. Nilai intensitas kegiatan KIR yang tertinggi justru ditunjukkan oleh dua siswa dengan kualitas kegiatan cukup. Penelitian juga menunjukkan bahwa tidak setiap siswa yang mengikuti program kegiatan ekstrakurikuler KIR secara intensif memiliki keterampilan menulis karya ilmiah yang tinggi. Sebaliknya, tidak setiap siswa yang tidak intensif mengikuti program kegiatan ekstrakurikuler KIR, menunjukkan keterampilan menulis yang rendah. Variasi nilai intensitas menunjukkan bahwa intensitas kegiatan ekstrakurikuler KIR tidak selalu berbanding lurus dengan keterampilan menulis dan kualitas kegiatan KIR siswa anggota KIR SMA Negeri 2 Malang. Dengan demikian dapat diketahui bahwa keterampilan menulis siswa tidak sepenuhnya diperoleh melalui intensitas keikutsertaan mereka pada program kegiatan ekstrakurikuler KIR atau dapat diartikan pula bahwa terdapat faktor-faktor yang memengaruhi ketidaksebandingan intensitas kegiatan KIR dengan keterampilan menulis karya ilmiah siswa.

Perbedaan kualitas kegiatan ekstrakurikuler KIR dalam kegiatan ekstrakurikuler KIR dipengaruhi oleh empat faktor yaitu, (1) motivasi siswa, (2) program kegiatan ekstrakurikuler itu sendiri, (3) iklim belajar di sekolah dan (4) kompetensi guru. Siswa dengan motivasi tinggi, akan mengikuti kegiatan ekstrakurikuler KIR dengan senang hati sehingga menunjukkan intensitas partisipasi yang tinggi terhadap program kegiatan KIR. Tingkat motivasi siswa tidak terlepas dari program kegiatan ekstrakurikuler KIR itu sendiri.

Program kegiatan ekstrakurikuler KIR dirancang dengan memperhatikan prinsip-prinsip ekstrakurikuler, termasuk prinsip menyenangkan. Menurut Supriatna (2010), terdapat enam prinsip kegiatan ekstrakurikuler yaitu prinsip individual, prinsip pilihan, prinsip keterlibatan aktif, prinsip menyenangkan, prinsip etos kerja, dan prinsip kemanfaatan sosial. Pelaksanaan KIR dengan mengabaikan prinsip kegiatan ekstrakurikuler dapat menurunkan motivasi siswa. Selain itu proporsi kegiatan kurikuler dan ekstrakurikuler yang tidak seimbang dapat menyebabkan siswa kehilangan motivasi mengikuti kegiatan ekstrakurikuler karena kelelahan. Keterampilan menulis karya ilmiah siswa dipengaruhi pula oleh kompetensi guru. Menurut Smith (1981) yang dikuatkan oleh Suparno dan Yunus (2011:4), pengalaman belajar menulis yang dialami siswa di sekolah tidak terlepas dari kondisi gurunya sendiri. Suparno dan Yunus menambahkan bahwa umumnya guru tidak dipersiapkan untuk terampil menulis dan mengajarkannya.

\section{Kemampuan Literasi Informasi Siswa}

Hasil penelitian menunjukkan bahwa kualitas kegiatan KIR siswa tidak selalu berbanding lurus dengan kemampuan literasi informasi mereka. Hal tersebut menunjukkan bahwa terdapat faktor yang memengaruhi hubungan kualitas kegiatan KIR dan kemampuan literasi informasi siswa. Hubungan kedua variabel ini dikemukakan oleh CONUL (2004:6), bahwa literasi informasi dapat memperjelas pemahaman siswa tentang proses penelitian, menghasilkan karya ilmiah yang lebih baik, meningkatkan keterampilan penggunaan sumber informasi, menghindari plagiarisme dan meningkatkan keberhasilan belajar siswa.

Tingkat hubungan yang lemah menunjukkan bahwa faktor-faktor memiliki pengaruh yang kuat. Berdasarkan sumber pengaruh, faktor yang memengaruhi nilai kemampuan literasi informasi siswa dipilah menjadi tiga. Faktor tersebut adalah (1) jumlah data, (2) kondisi personal siswa, dan (3) lingkungan siswa.

Perbedaan jumlah responden pada masing-masing variasi kualitas kegiatan KIR siswa berpengaruh terhadap kemungkinan perubahan nilai presentase. Nilai tingkat kualitas kegiatan KIR dengan banyak responden relatif lebih stabil daripada nilai tingkatan kualitas kegiatan KIR dengan satu responden. Kualitas kegiatan KIR dengan satu responden akan lebih mudah mencapai presentase perolehan skor maksimal atau skor minimal.

Setyowati mengemukakan bahwa kondisi personal siswa merupakan faktor yang berasal dari dalam diri masing-masing siswa secara personal yang bersifat unik sehingga setiap siswa dapat memiliki kondisi yang berbedabeda. Kondisi personal tersebut berupa kemampuan fisik, kemampuan psikis dan kemampuan intelektual yang dimiliki seseorang sejak lahir. Menurut Setyowati (2015:241), keterampilan literasi informasi seseorang dipengaruhi oleh modal manusia yang terdiri dari komponen yang bersifat bawaan lahir (innate) dan ada juga yang harus dikembangkan sendiri (acquired). Seseorang dengan kesempurnaan fisik tentu lebih mudah mencari dan memanfaatkan informasi yang daripada seorang disabilitas. Begitu pula dengan seseorang yang memiliki kecerdasan intelektual yang tinggi relatif lebih baik dalam menemukan penyelesaian masalah, mengembangkan strategi pencarian informasi, dan memanfaatkan informasi. Kemampuan bawaan ini menjadi pembeda kemampuan literasi informasi individu satu dengan lain sebagai akibat perbedaan kemampuan genetis yang tidak dapat diubah.

Faktor lingkungan merupakan hal-hal di luar kondisi fisik dan psikis siswa sebagai individu yang memengaruhi kemampuan literasi informasi. Faktor ini dapat berupa pendidikan, pelatihan, dan pengalaman siswa. Menurut Setyowati (2015:242), "Seseorang individu memiliki kontrol mutlak atas pengembangan modal manusia yang ia miliki". Kontrol pengembangan modal tersebut menjadi hak mutlak seseorang ketika sudah dewasa dan dapat menentukan keputusan yang rasional. Bagi anak-anak dan remaja, kontrol pengembangan modal ini dilakukan oleh orangtua, guru, masyarakat dan pemerintah melalui lembaga pendidikan dan lembaga sosial.

Hasil penelitian menunjukkan bahwa seluruh sampel memiliki kualifikasi nilai literasi informasi cukup. Hal ini menunjukkan bahwa kemampuan literasi informasi siswa KIR SMA Negeri 2 Malang merupakan perwujudan hasil usaha pribadi siswa. Berdasarkan hasil observasi dan wawancara tidak terstruktur, diketahui bahwa seluruh responden belum mengenal maksud dari literasi informasi dan memahami pentingnya kemampuan ini. 


\section{Korelasi Kualitas Kegiatan Ekstrakurikuler KIR dengan Kemampuan Literasi Informasi Siswa}

Korelasi kegiatan ekstrakurikuler dengan kemampuan literasi informasi ditinjau dari dua sudut pandang, yaitu dari sudut pandang intensitas dan sudut pandang keterampilan menulis karya ilmiah. Hubungan literasi informasi dengan intensitas latihan dikemukakan oleh beberapa ahli sebagai berikut. Menurut Nurchasanah dan Lestari (2013:5), "Menulis melibatkan pengetahuan, pengalaman, dan keterampilan dalam mengolah ide dan menalarkannya agar apa yang ingin disampaikan lewat tulisan sesuai dengan maksud yang diinginkan penulis". Dengan demikian, kegiatan menulis karya ilmiah tidak memerlukan kemampuan literasi informasi saja, melainkan juga memerlukan keterampilan menulis.

Intensitas latihan untuk mengasah keterampilan menulis, pengalaman trial and error, serta peningkatan kemampuan menulis dari segi teori dikemukakan pula oleh Tarigan (2008) dalam Zainurrahman (2011:2), bahwa keterampilan menulis dan membaca hanya dapat diperoleh dan dikembangkan melalui penguasaan konsep-konsep teoretis tertentu, disertai dengan latihan-latihan. Pendapat ini dikuatkan oleh pendapat ahli lain. Menurut Wardani (2006:1.5), "Menulis karya ilmiah adalah suatu keterampilan seseorang yang didapat melalui berbagai latihan menulis".

Hubungan kemampuan literasi informasi dengan keterampilan menulis karya ilmiah dalam rangka menemukan informasi yang tepat sebagai bahan penulisan karya ilmiah diungkapkan oleh Foster dan Wardani. Menurut Foster (2014:4-6), seorang peneliti berkerja dalam tiga tahap yaitu (1) menemukan sumber yang tepat, (2) mengorganisasikan skemata, dan (3) menerapkan standar penelitian. Seorang peneliti atau penulis karya ilmiah akan menyadari pentingnya literasi informasi dalam proses penelitian mereka sebagai akibat munculnya kebutuhan informasi dalam proses tersebut. Menurut Wardani (2006:17-23), cara pengumpulan informasi untuk penulisan karya ilmiah melalui perpustakaan, yaitu dengan membaca referensi berupa ensiklopedia, kamus, kompilasi fakta dan data statistik, bibliografi, panduan pencarian buku, panduan pencarian artikel, periodicals, terbitan pemerintah dan pemanfaatan katalog online.

Kemampuan literasi informasi yang terintegrasi dalam kegiatan menulis karya ilmiah ditegaskan oleh beberapa ahli. Proses penulisan karya ilmiah dibagi menjadi tiga tahap, yaitu tahap pramenulis, tahap penulisan dan tahap pascamenulis. Tahapan ini diungkapkan oleh Suparno dan Yunus (2011:1.15-1.25), bahwa proses menulis dipilah menjadi tiga tahap, yaitu tahap prapenulisan, tahap penulisan, dan tahap pascapenulisan.

Terdapat banyak aspek literasi informasi pada proses tersebut, terutama pada tahap pramenulis. Tahap pramenulis berfokus pada persiapan dan pengumpulan informasi tentang topik karya ilmiah, sistematika karya ilmiah, tata tulis karya ilmiah, dan ejaan. Informasi dikumpulkan dari berbagai sumber, kemudian dipilih dan dikelola sehingga memperoleh informasi dasar yang digunakan sebagai landasan penulisan karya ilmiah pada tahap ini. Menurut Proet dan Gill (1986) yang dikuatkan oleh Suparno dan Yunus (2011:15), "Tahap ini (prapenulisan) merupakan fase mencari, menemukan, dan mengingat kembali pengetahuan atau pengalaman yang diperoleh dan diperlukan penulis. Dengan kata lain, terdapat lima dari delapan aspek kemampuan literasi informasi pada tahap prapenulisan yaitu mengenali kebutuhan informasi, mengetahui sumber relevan, menentukan strategi pencarian, menemukan mencari, mengakses informasi, dan membandingkan serta mengevaluasi informasi. Oleh karena itu tahap pramenulis dikatakan sebagai tahap terpenting karena menentukan keberhasilan penulisan karya ilmiah. Menurut Tompkins dalam Sukino (2010), "Lebih dari 70\% waktu dalam menulis terletak pada tahap prapenulisan".

Tahap kedua, yaitu penulisan karya ilmiah, memerlukan ketepatan analisis informasi untuk memecahkan masalah penelitian. Tahap ini merupakan perpaduan dari kegiatan menelaah, menyeleksi, menyusun dan mengembangkan paparan menjadi sebuah karangan yang utuh dan padu. Suparno dan Yunus (2011:22), bahwa setelah melakukan tahap prapenulisan, seseorang telah siap menulis, mengembangkan butir-butir ide dengan memanfaatkan informasi yang telah dipilih dan dikumpulkan. Dengan kata lain, tahap ini memerlukan tiga dari delapan aspek kemampuan literasi informasi yaitu membandingkan dan mengevaluasi, mengorganisasi, menerapkan dan mengomunikasikan, serta mensintesis dan menyusun informasi baru.

Tahap pascapenulisan merupakan tahap akhir proses penulisan karya ilmiah. Tahap ini terdiri atas kegiatan mengevaluasi dan publikasi karya ilmiah. Melakukan evaluasi berarti menilai, mengidentifikasi kesalahan penulisan, mengoreksi kesatuan gagasan, dan mereduksi hal-hal yang kurang penting. Menurut Suparno dan Yunus (2011:25), "Fase ini (pascapenulisan) merupakan tahap penghalusan dan penyempurnaan buram yang dihasilkan. Kegiatannya terdiri atas penyuntingan dan perbaikan (revisi)."

Publikasi karya ilmiah memerlukan perhatian terhadap etika penulisan ulang informasi yang diperoleh dari sumber-sumber penelitian. Hal tersebut dilakukan untuk menghindari penulis dari tindakan plagiasi dan pelanggaran hak cipta. Menurut Bartol (1981) yang dikuatkan oleh Wardani (2006:32), menyebutkan tujuh faktor yang harus diperhatikan dalam penulisan karya ilmiah. Faktor ketujuh adalah 'apakah penelitian sudah berada pada tahap siap dipublikasikan'. Kesiapan yang dimaksud adalah etika penulisan ulang informasi. Dengan demikian dapat diketahui bahwa tahap pascapenulisan karya ilmiah memerlukan kemampuan literasi informasi aspek menggunakan informasi dengan etika.

Berdasarkan paparan tersebut dapat disimpulkan bahwa seseorang yang melakukan kegiatan menulis karya ilmiah, pasti melakukan kegiatan literasi informasi. Dengan kata lain, kegiatan literasi informasi merupakan kegiatan yang memiliki hubungan yang erat dengan kegiatan menulis karya ilmiah. Seseorang yang memiliki kemampuan literasi informasi dan intensitas latihan yang tinggi, seharusnya semakin terampil menulis karya ilmiah. Sebaliknya, semakin rendah kemampuan literasi informasi dan intensitas latihan seseorang, maka keterampilan menulis karya ilmiahnya akan semakin rendah.

Hasil perhitungan uji korelasi menunjukkan bahwa semakin tinggi kualitas kegiatan ekstrakurikuler KIR siswa, semakin cenderung tinggi pula kemampuan literasi informasi mereka. Derajat signifikansi pada hasil uji korelasi 
menunjukkan tingkat hubungan sangat lemah. Lemahnya hubungan kedua variabel menunjukkan bahwa faktor-faktor kualitas kegiatan ekstrakurikuler KIR dan kemampuan literasi informasi siswa memiliki pengaruh cukup kuat terhadap ketercapaian target keterampilan menulis karya ilmiah siswa anggota ekstrakurikuler KIR SMA Negeri 2 Malang.

Penelitian tentang kegiatan ekstrakurikuler KIR dan kemampuan literasi informasi pernah dilakukan oleh Hidayati dan Wijayanty. Hidayati (2011), menunjukkan bahwa kegiatan ekstrakurikuler KIR berpengaruh terhadap proses sains dan sikap ilmiah siswa. Proses sains yang dimaksud adalah merencanakan, melakukan, dan mengomunikasikan hasil penelitian. Proses sains merupakan aspek keterampilan dalam kegiatan penelitian, sedangkan kemampuan literasi informasi merupakan aspek pengetahuan yang mendasari pelaksanaan kegiatan penelitian. Wijayanty (2012), menunjukkan bahwa siswa kelas VIII telah memiliki kemampuan literasi informasi yang baik dalam mengerjakan makalah. Dengan demikian, hasil penelitian ini menyempurnakan kedua penelitian tersebut melalui pengukuran aspek pengetahuan siswa dalam proses penelitian, yaitu kemampuan literasi informasi siswa pada jenjang SMA. Penelitian ini juga menghubungkan kedua penelitian tersebut melalui pengukuran tingkat korelasi antara kegiatan ekstrakurikuler KIR dengan kemampuan literasi informasi siswa.

\section{PENUTUP}

Simpulan

Hasil penelitian menunjukkan bahwa siswa anggota KIR memiliki rata-rata skor kualitas kegiatan ekstrakurikuler KIR dengan klasifikasi cukup (skor 1.38). Rata-rata terendah (skor 0) ditunjukkan oleh siswa dengan kualitas kurang. Rata-rata tertinggi (skor 3) ditunjukkan oleh siswa dengan kualitas baik. Sebanyak enam siswa (37.5\%) memiliki kualitas kurang, sembilan siswa (56.25\%) memiliki klasifikasi cukup, dan sisanya, satu orang siswa (6.25\%) memiliki kualitas kegiatan KIR yang baik. Berdasarkan intensitas kegiatan, siswa dengan kualitas kurang menunjukkan intensitas kegiatan KIR yang paling rendah (20.37\%) daripada siswa dengan kualitas cukup (56.8\%) dan siswa berkualitas baik (100\%). Berdasarkan keterampilan menulis karya ilmiah, siswa berkualitas cukup menunjukkan presentase paling rendah (49.26\%) daripada keterampilan menulis karya ilmiah siswa dengan kualitas kurang (54.7\%) dan keterampilan menulis karya ilmiah siswa dengan kualitas baik (60.82\%).

Kemampuan literasi informasi siswa tergolong pada kualifikasi cukup dengan rata-rata 58.8\%. Kemampuan literasi informasi siswa dengan kualitas cukup menunjukkan presentase paling tinggi (60.29\%). Siswa dengan kualitas kurang menunjukkan kemampuan literasi informasi lebih rendah (58.5\%) dan siswa dengan kualitas baik menunjukkan kemampuan literasi informasi paling rendah (46.78\%).

Hasil analisis uji korelasi product moment pearson menunjukkan koefisien korelasi $\left(\mathrm{r}_{\text {hitung }}\right)$ sebesar $0.101<\mathrm{r}_{\text {tabel }}$ (2.15) dan nilai signifikansi sebesar $0.709>0.05$. Dengan demikian dapat disimpulkan bahwa terdapat hubungan positif antara kegiatan ekstrakurikuler KIR dengan kemampuan literasi informasi siswa SMA Negeri 2 Malang. Hal ini menunjukkan bahwa semakin tinggi kualitas kegiatan ekstrakurikuler KIR siswa, semakin cenderung tinggi pula kemampuan literasi informasi mereka.

\section{Saran}

Berdasarkan kesimpulan penelitian saran yang dapat dihasilkan sebagai bahan pertimbangan untuk memperbaiki kualitas kegiatan ekstrakurikuler KIR dan kemampuan literasi informasi siswa adalah sebagai berikut. Pertama, pembina ekstrakurikuler KIR dapat menyisipkan latihan kemampuan literasi informasi pada kegiatan menulis karya ilmiah untuk meningkatkan kualitas tulisan siswa. Kedua, guru mata pelajaran bahasa Indonesia dapat menyisipkan latihan kemampuan literasi informasi pada setiap materi menulis dan ikut berpartisipasi dalam pembinaan kegiatan ekstrakurikuler KIR di sekolah. Ketiga, peneliti lain dapat melakukan penelitian tentang kualitas ekstrakurikuler KIR dan kemampuan literasi informasi di sekolah yang berbeda dengan memperhatikan jumlah responden pada masingmasing variasi kualitas kegiatan KIR siswa untuk memperoleh kestabilan nilai pada masing-masing tingkatan kualitas.

\section{DAFTAR RUJUKAN}

Aedi, Nur. Instrumen Penelitian dan Pengumpulan Data, (Online), (http://file.upi.edu) diakses pada 3 Juni 2017.

CONUL. 2004. Integrating Information Literacy Into the Curriculum. New Zeland: CONUL Advisory Committee on Information Literacy (ACIL).

Foster, Nancy Fried. 2014. Information Literacy and Research Practices, (Online), (http://www.sr.ithaka.org) diakses 4 Juni 2017.

Harsiati, Titik. 2011. Penilaian dalam Pembelajaran. Malang: UM Press.

Hidayati, Umi. 2011. Pengaruh Kegiatan Ekstrakurikuler Kelompok IImiah Remaja (KIR) terhadap Keterampilan Proses Sains dan Sikap Ilmiah Siswa MAN Brebes 1, (Online), (http://lib.unnes.ac.id) diakses 1 Juni 2017.

Nurchasanah dan Lestari, Ida. 2013. Dasar-dasar Menulis Karya Ilmiah: Bahasa Indonesia Keilmuan. Malang: Aditya Media.

Sami' an. 2006. SPSS Korelasi, (Online),(http://samianstats.files.wordpress.com) diakses 4 Juni 2017.

Setyowati, Lis. 2015. Literasi Informasi Dilihat dari Perspektif Modal Manusia. (Online), (journal.stainkudus.ac.id) diakses 4 Juni 2017.

Suharsaputra, Uhar. 2012. Metode Penelitian: Kuantitatif, Kualitatif dan Tindakan. Bandung: PT. Refika Aditama. 
Sugiyono. 2006. Statistika untuk Penelitian. Bandung: Alfabeta.

Sukino.2010. Menulis Itu Mudah. Yogyakarta: Pustaka Populer.

Suparno dan Yunus, Mohamad. 2011. Keterampilan Dasar Menulis. Jakarta: Universitas Terbuka.

Supriatna, Mamat. 2010. Pendidikan Karakter Melalui Program Ekstrakurikuler,(Online), (http://file.upi.edu) diakses 2 Juni 2017.

Riadi, Edi. 2016. Statistika Penelitian: Analisis Manual dan IBM SPSS. Yogyakarta: Penerbit Andi

Wardani, I.G.A.K dkk. 2006. Teknik Menulis Karya Ilmiah. Jakarta: Universitas Terbuka.

Wijayanty, Erliya. 2012. Kemampuan Literasi Informasi Siswa di SMP Negeri 4 Depok (Online). (http://lib.ui.ac.id) diakses 1 Juni 2017.

Zainurrahman. 2011. Menulis: dari Teori hingga Praktik (Penawar Racun Plagiarisme). Bandung: Alfabeta. 